\title{
Influence of evaporative cooling by urban forests on cooling demand in cities
}

\section{Article}

\section{Accepted Version}

Creative Commons: Attribution-Noncommercial-No Derivative Works 4.0

Moss, J. L., Doick, K. J., Smith, S. and Shahrestani, M. (2019) Influence of evaporative cooling by urban forests on cooling demand in cities. Urban Forestry and Urban Greening, 37. pp. 65-73. ISSN 1618-8667 doi: https://doi.org/10.1016/j.ufug.2018.07.023 Available at https://centaur.reading.ac.uk/74637/

It is advisable to refer to the publisher's version if you intend to cite from the work. See Guidance on citing.

To link to this article DOI: http://dx.doi.org/10.1016/j.ufug.2018.07.023

Publisher: Elsevier

All outputs in CentAUR are protected by Intellectual Property Rights law, including copyright law. Copyright and IPR is retained by the creators or other copyright holders. Terms and conditions for use of this material are defined in the End User Agreement.

\section{www.reading.ac.uk/centaur}

\section{CentAUR}

Central Archive at the University of Reading 
Reading's research outputs online 

on cooling demand in cities

Joseph L. Moss ${ }^{1}$, Kieron J. Doick ${ }^{1}$, Stefan Smith², Mehdi Shahrestani ${ }^{2}$

1 Urban Forest Research Group

${ }^{2}$ School of the Built Environment 
Influence of evaporative cooling by urban forests on cooling demand in cities
6

1

2

3

4 5

7 


\section{Abstract}

9 Trees provide important ecosystem services to urban human society. Their absence can lead to more 10 pronounced environmental and social consequences, for example the urban heat island effect. 11 Evapotranspiration $\left(E_{t}\right)$ from trees reduces air temperature in the urban microclimate by converting 12 sensible heat to latent heat. Quantification and valuation of the ecosystem services provided by urban 13 trees is important for improving cost-benefit evaluations in support of protecting tree planting and 14 maintenance budgets and, thus, for building climate change resilience into cities. Inclusion of $E_{t}$ cooling 15 could improve ecosystem service valuation models by producing a more complete picture of the 16 benefits that urban trees provide to society.

This study explores two approaches for evaluating climate regulation as an ecosystem service of urban trees. Firstly, an enthalpy-based approach was adopted to valuate latent heat of evaporation from tree

20 transpiration (in three case study urban forests) by equating it to an equivalent service from an active 21 direct evaporative cooling system. Secondly, energy savings to air-conditioned buildings was modelled 22 using TRNSYS and TRNFLOW simulation programs with and without air precooled and humidified by 23 urban trees.

25 Trees are shown to provide substantial urban cooling with an annual valuation of $£ 84 \mathrm{~m}$ estimated using 26 the enthalpy-based approach, or ranging from $£ 2.1 \mathrm{~m}$ to $£ 22 \mathrm{~m}$ using TRNSYS and TRNFLOW dynamic 27 simulation programs; both for inner London case study. The latter savings arose from a modelled 1.28 28 13.4\% reduction in air-conditioning unit energy consumption. Challenges around assumptions of 29 homogeneity in both built form and urban forest canopy effects are discussed.

31 The case study examples highlighted differences in $E_{t}$ cooling between tree species, with Castanea 32 sativa, Prunus avium, Quercus petraea, Platanus hybrida and Fagus sylvatica typically providing more $E_{t}$ 33 cooling than any of the other tree species commonly found in urban forests. The research highlighted a 34 shortage of published $E_{t}$ data, particularly for urban environments.

\section{Key Words:}

37 Ecosystem services; Evapotranspiration; Urban cooling; Heat comfort; Bowen ratio. 
Introduction

39 Trees provide many benefits to people (Davies et al., 2017) and these have been collectively termed as 40 ecosystem services (ES) (Reid et al., 2005). Urban environments typically have considerably fewer trees 41 than rural environments, meaning that urban populations may have less access to the ES that trees 42 provide. In dense urban environments these ES can be of significant importance, for example helping to 43 mitigate the urban heat island (UHI) effect. This effect occurs where built-up areas absorb more heat 44 energy than surrounding rural environments and together with the high density energy fluxes from 45 human activity lead to pronounced increases in ambient surface and air temperature (Arnfield, 2003). 46 UHIs contribute to human heat stress and the plethora of associated health problems: for example, 47 Health Protection Agency (2012) reported that heat-related mortality already accounted for 2,000 48 premature deaths in the UK and forecast this to increase to around 10,800 premature deaths by 2080. 49 Mora et al. (2017) reviewing the international literature from 1980 to 2014 found 783 cases of heat50 related excess human mortality from 164 cities in 36 countries.

There is a positive correlation between locations that suffer from UHI and those that lack 53 evapotranspiring surfaces (Ca et al., 1998; Leuzinger et al., 2010) and the inclusion of green 54 infrastructure in urban environments has been identified as an effective way to mitigate UHI through 55 evapotranspiration ( $\left.E_{t}\right)$ (Gill et al., 2008; Ballinasa and Barradasa, 2015; Saaroni, et al., 2018). $E_{t}$ 56 associated with trees results in the release of water vapour from leaves into the air (Kozlowski and 57 Pallardy, 1997) that reduces the surrounding ambient air temperature through an evaporative cooling 58 process (Akbari, 2002). Trees and vegetation growing on or in close proximity to buildings also provide 59 multiple other benefits (Davies et al., 2017), including supporting biodiversity and reducing air pollutant 60 loading (Varghese et al., 2015). However, while urban forests (herein defined as "all the trees in the 61 urban realm" Davies et al., 2017) in temperate climates can produce a net cooling benefit by $E_{t}$, not all 62 trees offer the same level of cooling: canopy size and leaf amount are important determinants of species 63 and cultivar differences in water use (Stratópoulos et al., 2018), trees with high leaf area and 64 transpiration rate are the most effective in reducing air temperatures (Gillner et al., 2015; Rahman et al., 65 2018) and urban forests vary in their size and species and age-class composition (UFWAC, 2016).

67 Under a changing climate, cooling loads in buildings are expected to increase in the future (Jenkins et al., 68 2008). Mechanical cooling requirements can exacerbate the UHI effect by heat ejection to the 69 surrounding environment, adding to cooling loads across a city (Masson et al., 2014). Energy demand for 
cooling services can be reduced by the presence of urban trees through both shade casting (so called: shade-effect trees) and $\mathrm{E}_{\mathrm{t}}$ cooling (so called: climate-effect trees) (Akbari et al., 2001). Noting that peak

72 urban electric demand rose by $2-4 \%$ for each $1^{\circ} \mathrm{C}$ rise in daily maximum temperature, Akbari (2002) 73 reported potential cost savings of up to $\$ 200$ per tree. However, the effect of $E_{t}$ was not considered and 74 the level of benefit varied by climate region. Reviewing the literature, Doick et al. (2013) reported that in 75 temperate climates the role of shading and evapotranspiration are approximately equal. This study is 76 concerned with the $\mathrm{E}_{\mathrm{t}}$ cooling of urban trees.

$\mathrm{i}$-Tree Eco is a tool within the i-Tree suite of peer-reviewed software tools (i-Tree, 2017). It is based on the UFORE (Urban Forest Effects) methods (Nowak and Crane, 1998) and has been developed to support 80 urban forest management through the quantification of urban forest characteristics, and analysis and 81 valuation of the ES that they provide ( $i$-Tree, 2017). Climate regulation from $E_{t}$ cooling is an ES not 82 currently included in i-Tree Eco. However, the UFORE method has the capability to model leaf area at 83 the species level and total canopy surface area for a given location (Nowak and Crane, 2003). Latent 84 heat transfer across an urban forest could be calculated if appropriate $E_{t}$ rates were considered. Indeed, $85 E_{t}$ cooling is likely to be substantial on a city-wide scale (Gillner et al., 2015) given maximum 86 transpiration rates for individual trees can be many hundreds of litres per day (Hsieh et al., 2018; 87 Stratópoulos et al., 2018).

The quantification and valuation of ES is of growing international interest within a context of natural capital accounting (NCA) (UN et al., 2012). Indeed, the UK government is interested in developing accounts for a broad range of UKNEA habitats including woodland and urban (Defra/ONS, 2017). A scoping study to develop an urban NCA for the UK incorporated inter alia the climate regulation ES, with 93 valuation based upon both the ISO standard 7243 estimates of productivity loss at different outdoor 94 temperatures and an i-Tree Eco based estimation of building energy use avoided due to the presence of 95 urban trees (Eftec, 2017). The former determines the loss in productivity with and without air 96 temperature reduction by urban green infrastructure to value the contribution of this ES in terms of 97 maintaining productivity and notes methodological limitations of an assumed average cooling effect of 98 parks and woodland. The latter considers the impact of tree shade and shelter on summer cooling 99 energy (avoided use of air conditioning) as well as winter warming (reduced requirement for electrical 100 warming). This approach is limited however by the lack of adaptation of the i-Tree module for UK 101 building types. Both approaches excluded the saving related to the non-emission of $\mathrm{CO}_{2}$. Indeed, a 
comprehensive valuation of this ES is complicated by the multiple ways that trees impact urban temperatures and, thus, the numerous savings mechanisms that could be considered.

This study aimed to evaluate the impact of urban trees on 1) mechanical cooling loads in buildings, and 2) energy cost savings associated with cooling ambient air by mechanical means. Energy saving was 107 evaluated through a) direct comparison of $E_{t}$ to evaporative cooling using an enthalpy-based approach 108 to valuate latent heat of evaporation from tree transpiration, and b) by incorporation of $E_{t}$ into 109 established dynamic building thermal and air flow modelling programs - TRNSYS and TRNFLOW. 110 Valuation of the climate regulation ES could provide a useful complement to tools, such as i-Tree, that 111 show the wide range of benefits of urban trees, as well as emergent NCA methodologies.

\section{Methodology}

\section{Evapotranspiration rate of trees}

115 Values for $E_{t}$ and stomatal conductance $\left(g_{s}\right)$ were gathered from published literature for tree species relevant to urban environments within a temperate oceanic climate: namely 'Cfb' from the Koppen-

117 Geiger Climate Classification (Kottek et al., 2006) and 'Do' from the Köppen-Trewartha Climate 118 Classification (Belda et al., 2014). Where only $g_{s}$ data was available, $E_{t}$ rate $\left(E_{t} R\right)$ was calculated using 119 Fick's law of diffusion, after Rahman et al. (2011), and converted to units of $\mathrm{g} / \mathrm{m}^{2} / \mathrm{s}$. Table 1 presents the minimum, mean and maximum $E_{t}$ for the range of species and cultivars used in this study.

122 [Insert table 1: Evapotranspiration rates for tree species, sourced from the published literature.]

Analysis of $E_{t} R$ was conducted to consider the range of values reported in the literature. Stomatal conductance, and therefore $E_{t} R$, has high temporal (especially daily) and spatial variability, affected by factors such as water vapour pressure deficit, soil moisture, plant health, position orientation and age of 127 leaves (or needles) (Breuer et al., 2003). To account for such variations as far as reasonably possible 128 minimum, mean and maximum values from the literature were considered in this study. Figure 1 shows the mean $E_{t} R$ for eight tree species and three genera where multiple records are reported; minimum and maximums are shown as vertical bars. Single $E_{t} R$ values for the other 17 tree species and one genus 131 listed in Table 1 are also shown. The average $E_{t} R$ across all records was $0.058+/-0.012 \mathrm{~g} / \mathrm{m}^{2} / \mathrm{s}(95 \%$ 132 confidence interval; solid and dashed blue horizontal bars, respectively, in Figure 1). Three of the genus 133 values and twelve of the tree species $E_{t} R$ (minimum, mean or maximum) values fell within the $95 \%$ 134 confidence intervals of the all-data average. $E_{t} R$ has a linear relationship to the amount of cooling 
provided; therefore the range of $E_{t} R$ for each of the species is indicative of the uncertainty associated 136 with the cooling results.

137

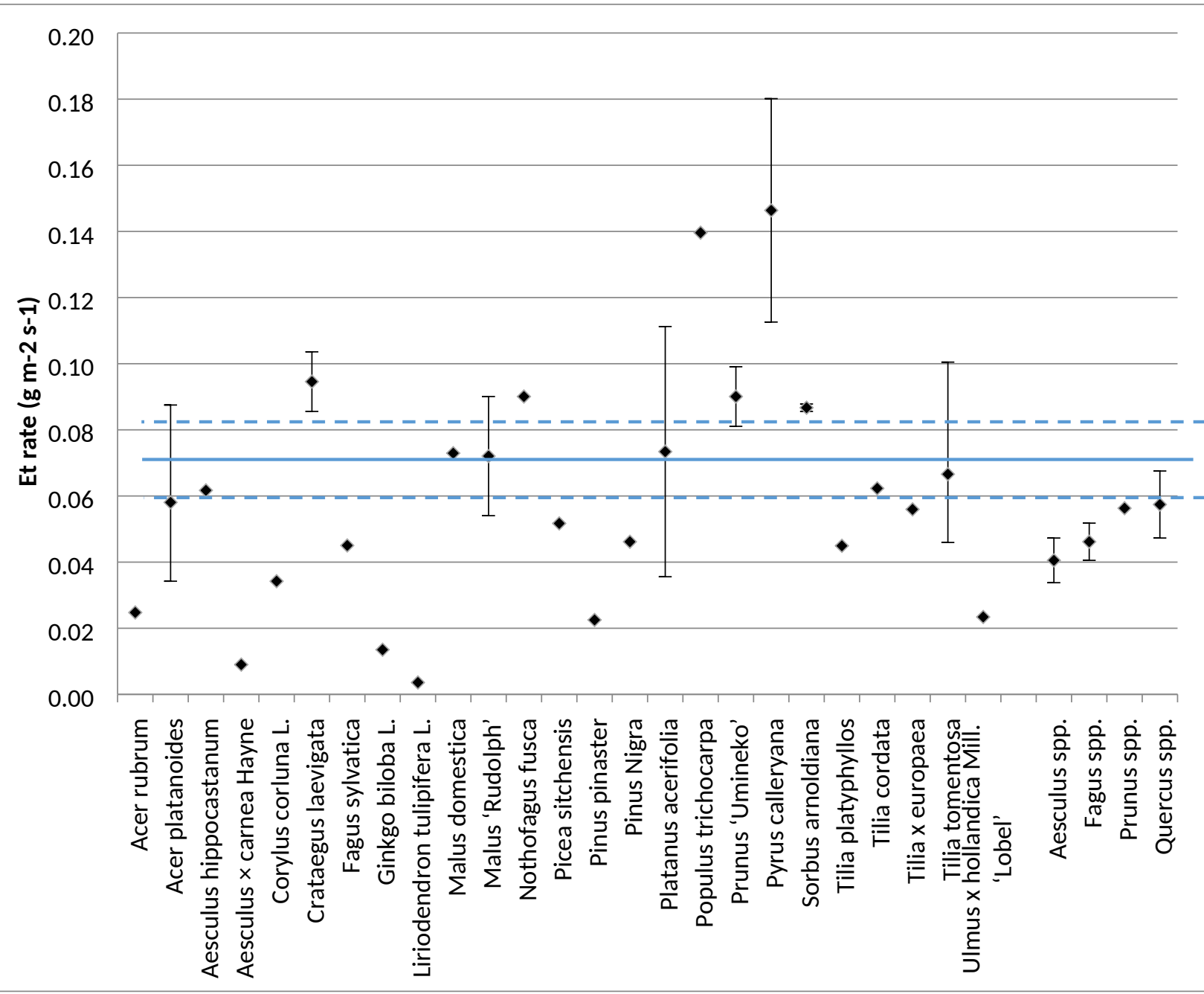

Figure 1. Mean evapotranspiration rates $\left(E_{t} R\right.$; black diamonds) for all of the tree species considered; sourced from the published literature. Minimum and maximum $\mathrm{E}_{\mathrm{t}} \mathrm{R}$ are shown by vertical bars. For genera with multiple values in the literature, the genus average and range are shown. The mean of all the species and genera $E_{t} R$ and the $95 \%$ confidence interval of this mean are presented (solid horizontal line, upper and lower intervals as dash horizontal

144

\section{Evapotranspiration from an urban forest}

146 Three case studies were considered, each having a completed i-Tree Eco survey: Edinburgh (Hutchings et 147 al., 2012), Greater London (Rogers et al., 2015), and Wrexham (Rumble et al., 2015). For Greater 148 London, the Outer and Inner London figures as detailed in the study are used. The species composition 
and total leaf area values, as reported by $\mathrm{i}$-Tree $\mathrm{Eco}$, were used in conjunction with Table $1 \mathrm{E}_{\mathrm{t}} \mathrm{R}$ values to provide a total $E_{t}$ for each case study urban forest. Total $E_{t}$ was determined using the species mean $E_{t} R$ where possible; where a species mean was not available, the genus average $E_{t} R$ was adopted. Where neither species nor genus data were available, the all-data mean $E_{t} R$ was used (Table 1). $E_{t}$ was normalised across the case studies according to land surface area $\left(\mathrm{E}_{\mathrm{t}} / \mathrm{km}^{2}\right.$; assuming an even distribution 154 of trees).

The rate of water mass transfer, $\dot{m}\left(\mathrm{~g} / \mathrm{m}^{2} / \mathrm{s}\right)$, for $\mathrm{E}_{\mathrm{t}}$ was converted into rate of thermal energy absorbed, $\dot{q}\left(\mathrm{~kJ} / \mathrm{m}^{2} / \mathrm{s}\right)$, from the surrounding environment using Eq. 1:

158

$$
\dot{q}=\dot{m} \times \lambda_{v H_{2} o}
$$

160

Where $\lambda_{v_{\mathrm{H}_{2} \mathrm{O}}}$ is the latent heat of vapourisation of water $\left(\lambda_{v_{\mathrm{H}_{2} \mathrm{O}} \mathrm{O}}=2.456 \mathrm{~kJ} / \mathrm{g}\right.$ at $292 \mathrm{~K}$ and atmospheric pressure; Wagner and Pruss, 2002). Calculating energy transfer rate allowed $E_{t}$ to be related to cooling 163 164 as a measure of power (i.e. $\mathrm{E}_{\mathrm{t}}$ power). For modelling purposes, it was assumed that tree leaves had zero heat capacity (Ca et al., 1999).

The distribution of heat from $E_{t}$ cooling can be generally characterised by the Bowen ratio (B) 167 (Santamouris, 2013). Guided by Taha (1997), the Bowen ratios of 'typical' UK urban and wooded areas 168 were used to apply an adjustment factor of $0.5 .\left(B_{\text {tree }}+1 / B_{\text {urban }}+1\right)$ to calculated $E_{t}$ energy values. This 169 generalised adjustment factor does not consider local spatial factors, but provides an estimate for the amount of energy that equates to cooling, i.e. the effective $E_{t}$ cooling potential.

172 A common method of assigning a monetary value to ES is to use a comparative service as an economic 173 benchmark (Defra/ONS, 2017). Following the methodology of Rahman et al. (2011), an economic 174 assessment of $E_{t}$ cooling from trees was made through direct comparison with the cost to provide 175 equivalent cooling from operating an air conditioning $(\mathrm{A} / \mathrm{C})$ unit. An active direct evaporative cooling 176 system (DEC) was used for comparison because the cooling mechanism is the same as $E_{t}$ from trees 177 (Amer et al., 2015). A mid-sized evaporative cooler was selected (model ECP07, EcoCooling Ltd, 178 www.ecocooling.org). This model provides $35 \mathrm{~kW}$ of cooling from $1.5 \mathrm{~kW}$ of electricity and a flow rate 179 range $10-14.5 \mathrm{~m}^{3} / \mathrm{hr}$. The $B$-adjusted $E_{t}$ cooling power of the trees was divided by the rated cooling 180 capacity of the evaporative cooler $(35 \mathrm{~kW})$ to give the number of $\mathrm{A} / \mathrm{C}$ units required to deliver an 
equivalent amount of cooling as the three case study urban forests. This value was then multiplied by

182 electricity consumption of the cooler $(1.5 \mathrm{~kW})$ and an electricity unit price of $0.14 \mathrm{f} / \mathrm{kWh}$ (UK average 183 electricity variable unit 'Direct Debit' and 'Prepayment' tariffs for 2017; BEIS, 2018) to provide an 184 equivalent cooling value $(£ / \mathrm{hr})$. The comparison is made with the operational cost of $A / C$ units and does not include purchasing or maintenance costs.

The potential energy impact of evapotranspiration on building cooling systems

The direct comparison method described above is limited conceptually as A/C units are not designed for outdoor use. However, the results provide useful comparison to previous work. A more realistic, though novel, approach is to recognise that trees are cooling the outdoor ambient air, which in turn impacts the cooling load placed on A/C systems. Through building energy modelling the energy dynamics and local spatial factors of different types of building structures found in UK cities were used to assess the impact of $E_{t}$ cooling by urban trees on building energy consumption. This approach provided a practical scenario that is transferable to building energy cost savings.

Modelling energy impact on a single building and a street canyon

To evaluate how trees cooling the surrounding environment impacts on a building's cooling requirement a dynamic thermal energy model: TRaNsient SYstems Simulation package (TRNSYS) (TRNSYS, 2010) with airflow analysis by TRNFLOW (TRNFLOW, 2009), was employed to capture both the indoor and outdoor processes. TRNSYS is a reference software and one of the listed simulation programs in the European/British Standard on thermal solar systems and components: BS/EN12977 (2018). TRNSYS is a recognised simulation package within the 'Best Directory of Building Energy Software Tools' (formerly hosted by US Dept. of Energy) and has been tested and validated by International Energy Agency (IEA; under Task 34/43). The IEA comprehensive study demonstrated the robustness of the algorithms used in the TRNSYS (Loutzenhiser et al., 2007; Neymark et al., 2008). In addition, the software has been successfully used over multiple decades in a broad range of built environment research (Bradley and 207 Utzinger, 2007; Shahrestani et al., 2013; Shahrestani et al., 2017; Antoniadis and Martinopoulos, 2018; 208 Stritih et al., 2018).

While, ultimately, the cooling load of a building is determined by the many different physical attributes 211 of the indoor and outdoor environment (i.e. solar gains, humidity, surface temperatures, air 212 temperature, wind speed, heat capacity and orientation), the indoor air conditions control the level of 213 cooling demand and the outdoor air temperature influences the energy requirement to meet that 
cooling demand. For this reason, the modelling was broken into two conceptual parts: (i) $E_{t}$ influence on 215 outdoor air temperature, and (ii) a simplified representation of a building to understand cooling demand 216 at a given cooling set-point temperature, as the energy needs for cooling are also impacted by relative 217 humidity (RH).

218

219 For this element of the research, Inner London was adopted as the case study area. Using the i-Tree Eco 220 published leaf area density and the average $E_{t} R$ for the urban forest composition of Inner London it was possible to determine the change in absolute humidity of the volume of air surrounding a building (or in a street canyon, see below) at a given moment in time. Modelling the $E_{t}$ effect of trees as an evaporative cooling process with constant enthalpy, a psychrometric chart (Supplemental Figure 1) was used to 224 determine a temperature drop in the air surrounding the trees, assuming that the entire $\mathrm{E}_{\mathrm{t}}$ was used in 225 cooling the air, and that effects remained local to the tree and buildings (i.e. no boundary layer mixing). The minimum, mean and maximum $\mathrm{E}_{\mathrm{t}} \mathrm{R}$ (Table 1 ) were applied to the leaf area density of Inner London (from Table 2) and scaled to a modelled building area (Figure 2). This scaled $\mathrm{E}_{\mathrm{t}} \mathrm{R}$ was used to calculate a temperature drop in a volume of air immediately surrounding the simplified representations of a building, and these representations were assumed to be homogenously representative of Inner London when scaling the energy efficiencies for valuation purposes.

Two zonal models were developed using TRNSYS: (i) a single zone building in isolation, and (ii) a street canyon consisting of two single zone building blocks in parallel (Figure 2). In each, shade-casting by trees onto the buildings is not considered by the model; in the latter case, mutual shading of buildings is modelled. Each considered the influence of regional weather conditions (larger scale weather systems) on cooling as well as capturing some of the mixing processes of buoyancy and forced flow direction of air. A weather file representative of conditions of London (after: Levermore and Parkinson, 2006), determined the boundary conditions of the model at each time step. The single zone isolated building was $10 \mathrm{~m} \times 10 \mathrm{~m} \times 20 \mathrm{~m}(\mathrm{~h} ; \mathrm{w} ; \mathrm{l})$ and situated centrally in a total volume of $20 \mathrm{~m} \times 30 \mathrm{~m} \times 20 \mathrm{~m}(\mathrm{~h} ; \mathrm{w} ; \mathrm{l})$. For the street canyon, each building block was $18 \mathrm{~m} \times 20 \mathrm{~m} \times 100 \mathrm{~m}$ (h;w;l) in a total volume of $36 \mathrm{~m} \times 80 \mathrm{~m} \times$ $100 \mathrm{~m}(\mathrm{~h} ; \mathrm{w} ; \mathrm{l})$. Simulations ran at $1 \mathrm{hr}$ time steps from January $1^{\text {st }}$ to December $31^{\text {st }}$.

243 The cooling season was taken as June $1^{\text {st }}$ to September $30^{\text {th }}$ - the warmest of the British summer 244 months. A constant $E_{t}$ was applied for the single building case and for the street canyon a fixed daily 245 profile of $E_{t}$ was applied following a simple polynomial curve based on work by Gerosa et al. (2012) to 
account for hourly changes in canopy transpiration. A $4^{\text {th }}$ order polynomial was applied (Equation 2).

247 Building cooling was considered to be available $24 \mathrm{hr}$ a day with the cooling limited to a temperature 248 set-point of $23^{\circ} \mathrm{C}$ and a RH set-point of $50 \%$, or $60 \%$. A constant system Coefficient of Performance (CoP) 249 of 2.0 was applied, as was the electricity unit price (0.14 £/kWh; BEIS, 2018).

$$
\mathrm{E}_{\mathrm{t}}=\left\{\begin{array}{lr}
\left(0.00022(\mathrm{t}-13)^{4}-0.03(\mathrm{t}-13)^{2}+1\right) \times \mathrm{E}_{\mathrm{t} \max } & 6 \leq \mathrm{t}<21 \\
0 & \mathrm{t}<6 \text { or } \mathrm{t} \geq 21
\end{array}\right.
$$

where $E_{t m a x}$ is the maximum $E_{t}$ for the day and $t$ is time, in 24 hr clock system.

Each building block had the same schedule of operation, set point cooling temperature, occupant density and internal heat gains (see Supplemental Material: Table S1).

(a)

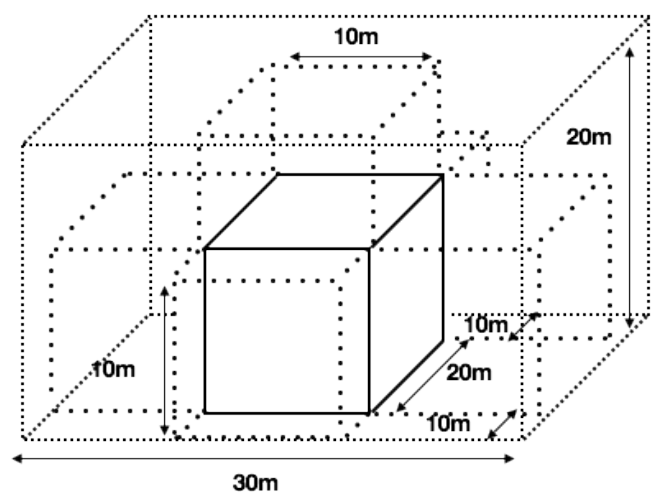

(b)

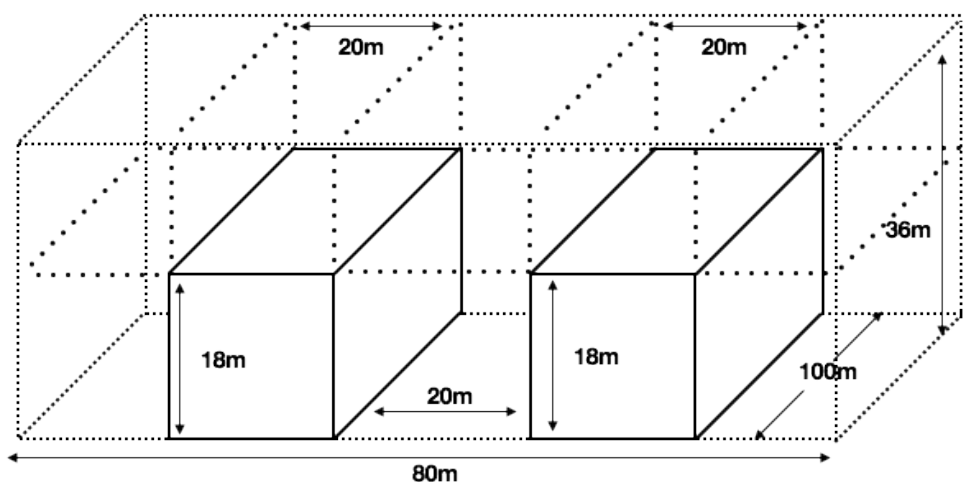

258

259

260

261

262

263

264

265

266

267

268

269

270

Figure 2. Model dimensions for representing (a) single, isolated building, and (b) a street canyon and row of buildings with each row considered as a single open plan zone. The surrounding volume (black dashed line) determined the area for calculating availability of $E_{t}$. Air flow from wind and buoyancy effects was considered by splitting the surrounding volume into equally sized sub-volumes, as depicted by the blacked dotted line. Each cuboid represents a different microclimate surrounding the building cuboid (solid black lines).

Ambient conditions are not only important to determining the loads under which a cooling system operates, but are also important for determining the influence of air infiltration and ventilation rates on cooling demands. For this study, the building ventilation was considered to be $100 \%$ mechanically driven in order to ascertain the level of cooling load offset provided by trees. Infiltration, however, is dependent on the pressure coefficients $\left(C_{p}\right)$ on the surface of a building - important to airflow network 
programs (Cóstola et al., 2009). Whilst there is recognised uncertainty in use of standard $C_{p}$ values, for a

272 first approximation the values provided by (Grosso, 1992) using the CpCalc+ calculation program were 273 applied to provide representative values of a building over 3 storeys in height. $C_{p}$ values applied in the 274 two models are shown as Supplemental Material (Table S2).

\section{Results}

277 Case study areas

278 Urban forest composition was similar across each case study area and for many of the genera $E_{t} R$ values 279 were available from the literature (Table 1). The most important species for providing $E_{t}$ cooling were 280 also similar across the case studies, with at least two of Castanea sativa, Prunus avium or Platanus 281 hybrida featuring in the top three (Table 2). Edinburgh had the second highest number of trees per $\mathrm{km}^{2}$ 282 but the lowest normalised leaf area (Table 3). Outer London had fewer trees $/ \mathrm{km}^{2}$ but $27 \%$ more leaf 283 area than Edinburgh, suggesting that Outer London's trees have larger canopies or species with larger 284 leaves. Inner London's trees evapotranspired the most: on average $26.5 \mathrm{~kg} \mathrm{H}_{2} \mathrm{O} / \mathrm{tree} / \mathrm{hr}$ (Table 3). Total 285 transpiration varied from $1,420 \mathrm{~kg} \mathrm{H}_{2} \mathrm{O} / \mathrm{s}$ in Wrexham to $44,900 \mathrm{~kg} \mathrm{H}_{2} \mathrm{O} / \mathrm{s}$ in Outer London (Table 3). 286 When normalised by leaf area or case study area $\mathrm{E}_{\mathrm{t}}$ ranged 47.4-54.1 $\mathrm{kg} \mathrm{H}_{2} \mathrm{O} / \mathrm{s} / \mathrm{km}^{2}$ (by leaf area, Table 287 3) or $30.4-37.7 \mathrm{~kg} \mathrm{H} \mathrm{O}_{2} \mathrm{O} / \mathrm{km}^{2}$ (by land area, data not shown).

289 [insert Table 2. The three most common tree species and most important species for delivering $E_{t}$ 290 cooling in each of the case study urban forests]

291 [insert Table 3. Evapotranspiration across the case study urban forests]

Table 4 presents results for $E_{t}$ cooling for each of the case study urban forests. Adjusted total $E_{t}$ cooling 294 energy $(q)$ is presented along with the equivalent number of $A / C$ units required to provide the same amount of cooling, value of cooling and the $95 \%$ confidence interval. Outer London with the largest urban forest and corresponding leaf-area (Table 3) produced the greatest total amount of cooling at $55,200 \mathrm{MW}$ (Table 4) or $£ 321 \mathrm{~m} /$ annum in $\mathrm{A} / \mathrm{C}$ unit equivalents (assuming cooling $8 \mathrm{hr} / \mathrm{day}$, June 298 through Sept; $£ 83.9 \mathrm{~m} /$ annum for Inner London). When normalised 'per tree' the range in the average 299 values of cooling was $4.8 \mathrm{~kW} /$ tree (Wrexham) to $9.1 \mathrm{~kW} /$ tree (Inner London); equivalent to 0.03 to 0.05 $300(+/-0.01) \mathrm{f} / \mathrm{hr} /$ tree across the three urban forests (Table 4). The power ratings on a per tree basis are 301 comparable to those reported by Rahman et al. (2011) who reported 1.4, 3 and 7 kW/tree for Pyrus 302 calleryana in August growing in Amsterdam soil, grass verge or pavement, respectively. 
[insert Table 4. Summary of the estimated value of the effective cooling from each urban forest case study]

306

307 Urban building energy savings - Single building model

308 On average, the level of reduction in cooling resulting from current levels of tree provision in Inner 309 London ranged between 0.6 and 0.9\% depending on indoor RH control levels (Table 5). Day et al. (2009) 310 estimated that London accounted for $11 \%$ of Britain's total cooling load. Assuming that this almost 311 exclusively applies to Inner London (i.e. 9 of the 11\%), and taking the official government figures on total 312 cooling load for the UK in 2016 to be 13,037 GWh (BEIS, 2017), then the trees in Inner London provide a 313 cooling benefit of $7.0-10.6 \mathrm{GWh}$. Taking a midpoint of $8.8 \mathrm{GWh}$ and a unit price of $£ 0.14 / \mathrm{kWh}$, the 314 saving equates to $£ 1.23$ million per year under the current assumptions.

315 [inset Table 5: Total cooling supplied to single building with and without tree $\mathrm{E}_{\mathrm{t}}$ cooling applied and for 316 different $\mathrm{RH}$ control set points]

318 Urban building energy savings - Street canyon building model

319 The cooling energy provided by Inner London trees at the three rates of $E_{t}$ (minimum, mean, maximum) 320 are presented in Table 6. In the case of sensible cooling loads, trees in Inner London produced between $321 \quad 1.28 \%$ and $13.4 \%$ energy saving when $\mathrm{RH}$ of the building indoor environment was not controlled for. 322 However, the latent cooling load increased in all instances as a result of the increased moisture from the $323 E_{t}$ of trees. Accounting for both sensible and latent cooling loads, the presence of trees would cause an 324 increase of between $0.09-1.15 \%$ when controlling indoor environments to $23^{\circ} \mathrm{C}$ at $50 \% \mathrm{RH}$, but would 325 result in a decrease in cooling load of between $0.9 \%$ and $3.09 \%$ for an indoor $\mathrm{RH}$ of $60 \%$. Cooling systems 326 rarely (if at all) operate to tightly control indoor $\mathrm{RH}$ and as such the latent energy component of a 327 building cooling system is likely to be much lower than shown here. Looking, therefore, at the effect on 328 sensible cooling alone, a reduction of $1.28-13.4 \%$ in cooling demand for a typical summer could be 329 associated with the presence of trees in Inner London when considering the full $95 \%$ confidence interval 330 of species $E_{t}$ rates. This equates to an annual cost saving of between $£ 2.1$ million to $£ 22.0$ million for a 331 typical cooling season in Inner London (assuming that the savings in energy usage are applicable pan332 Inner London and that 9\% of the 13,037 GWh (BEIS, 2017) total cooling load for the UK applies to Inner 333 London, as above). 
[insert Table 6. Cooling energy demand and saving potential from trees for a range of $E_{t}$ for the street canyon model scenario and with separation of sensible and latent cooling loads]

\section{Discussion}

\section{Evapotranspiration Data}

339 Review of the available literature revealed that $E_{t} R$ is significantly influenced by the characteristics of 340 plants and weather conditions (Heath, 1998; Atkinson et al., 2004). In this study, therefore, $E_{t}$ data were 341 only used from studies in regions with similar climate to the UK. Of the 25 species for which $E_{t}$ data were 342 available, ten were not present in any of the case study's urban forests (Table 1); data for these 343 subsequently featured in the genus average values. The influence of sunlight, temperature, humidity, 344 water availability, and wind speed on $E_{t}$ means that even within a single species, variation within a city 345 due to microclimatic effects should be expected. Kruijt et al. (2008) and Bernacchi et al. (2011) have 346 shown the impact of air quality $\left(\mathrm{CO}_{2}\right.$ and $\mathrm{O}_{3}$ concentrations) on the rate of $\mathrm{E}_{\mathrm{t}}$; and Heath (1998) showed 347 daily variation in $g_{s}$ due to meteorological conditions. In this study, the variation of these influencing 348 factors was accounted for through the use of minimum, mean and maximum $E_{t}$, only. One limitation of 349 the study, therefore, is uncertainty due to changes in $\mathrm{E}_{\mathrm{t}}$ under prolonged drought-stress conditions. Gill 350 et al. (2013) note: increased length and frequency of summer droughts is likely to decrease the cooling 351 potential of $E_{t}$, when it is most needed. Furthermore, $E_{t} R$ values were not available at the species-level 352 for ca. $90 \%$ of the three urban forests (data not shown). However, applying the range of $E_{t} R$ values 353 allowed estimation of a range of $E_{t}$ cooling provided and further insight to the benefit of trees in urban 354 settings that may otherwise go unrecognised yet is useful in urban planning and urban forestry 355 management policy creation.

357 Evapotranspiration from an urban forest

358 The two defining parameters of $E_{t}$ in this study are $E_{t} R$ and leaf area. Species, genus and overall-average $359 \quad E_{t} R$ were assumed not to differ between the three case studies. The validity of this assumption should be 360 tested further to check the applicability of the approach to cities across UK, Europe and areas of similar 361 climate; however it was considered appropriate for this study due to the use of minimum, mean and 362 maximum published values. Given this assumption, leaf area was the main parameter determining total $363 E_{t}$ and hence cooling. An urban forest with more healthy mature and large stature trees will typically 364 have a larger leaf area and, therefore, offer greater cooling potential. The case for more large stature 365 trees in the urban environment is frequently made (e.g., UFWACN, 2015) on intuitive (a larger canopy de 
facto casts more shade) as well as scientific argument (Rahman, et al., 2018; Smithers, et al., 2018, for

367 example). Our results support such claims: by virtue of their greater cumulative leaf areas larger 368 canopied trees provided more of the climate regulation ES. Table 1 illustrates, however, that small 369 stature trees including: Crataegus laevigata, Prunus 'Umineko', Pyrus calleryana and Sorbus arnoldiana 370 have average $E_{t}$ rates that suggest they can be significant contributors to latent heat transfer $\left(E_{t}>0.075\right.$ $\left.371 \mathrm{~g} / \mathrm{m}^{2} / \mathrm{s}\right)$. Their size means that these species can be suited to a range of planting locations, for example 372 where there is insufficient room for a tree of large stature. Stratópoulos et al. (2018) showed that some 373 small to medium stature trees, including Acer campestre and Ostrya carpinifolia, showed higher 374 flexibility in response to changing weather with increased growth and transpiration under favourable 375 conditions and more conservative water use when dry. Their inclusion in the urban forest may thus 376 support efforts to build resilience to a changing climate through species diversification, however 377 widespread use may reduce delivery of evapotranspirational cooling due to the regulated water use of 378 these species.

Building energy efficiency

381 The results showed that $\mathrm{E}_{\mathrm{t}}$ from the trees in Inner London is likely to provide significant energy savings 382 due to the already high and increasing cooling energy demand. Even a reduction as small as $1 \%$ equated to a substantial financial benefit - $£ 1.64 \mathrm{~m}$ - yet the study revealed that evaporative cooling may 384 contribute a saving of up to a $13.4 \%$ reduction in energy consumption for sensible heat cooling. At the 385 same time, moisture content in the microclimate is increased and this may increase the demand for 386 latent cooling in buildings, which highly depends on the approach of humidity control in the indoor 387 environment. For instance, under a very tight control of $\mathrm{RH}$ to $50 \%$, $\mathrm{E}_{\mathrm{t}}$ may lead to an increase to total 388 cooling demand by up to $1.15 \%$. But this is without consideration of other cooling mechanisms 389 associated with trees (shading and short-wave energy reflection; Smithers et al., 2018). Furthermore, it 390 is highly atypical for cooling systems to operate under tight humidity control, especially in the UK. Under 391 the more realistic RH control mechanisms and set-point of $60 \%$, the modelling showed that $E_{t}$ from trees 392 contributed an annual energy consumption saving across Inner London of up to $3.1 \%$ (when considering 393 sensible and latent cooling together), equivalent to $£ 5.09 \mathrm{~m}$. If energy savings due to the shade-effect 394 was also valued, the climate regulation ES valuation is likely to be even greater (Akbari et al., 2001; 395 Akbari, 2002; Hsieh et al., 2018). 
In using a combination of published $\mathrm{E}_{\mathrm{t}}$ rates, tree population survey data and a first order modelling 398 estimate of impact on cooling load, certain limitations in the estimates must be recognised. The results 399 demonstrate value can be attributed to tree cooling, however the assumptions of homogeneity in both 400 built form and urban forest canopy effects are limiting factors. The figures should be considered as 401 estimates on order of magnitude. The mixing of air in the urban canopy layer and impact of building 402 height on availability of tree cooling needs further consideration to demonstrate the impact of trees on 403 cooling energy demand. Addressing some of the assumptions in this work could lead to a reduction in 404 this estimated potential saving. Consideration of specific microclimatic effects - such as increased 405 localised air temperatures leading to increased vapour pressure deficit and thus increased $E_{t}$ (Peters et 406 al., 2010) - could also, however, demonstrate increased cooling load offsets. Turbulence and mixing of 407 air in the canopy layer immediately around a building have in part been accounted for by use of a zonal 408 model that captured some of the mixing processes of buoyancy and forced flow direction of air. To 409 represent the diffusion of cooling to the wider urban boundary layer and to take account of local (urban 410 canyon) temperature variations (Grimmond, 2007) a more sophisticated modelling approach may be 411 warranted. Furthermore, the study has not considered the influence that vegetative and built surface 412 fractions can have on energy fluxes (Lorridon and Grimmond, 2012). Selection of different sites could 413 lead to more representative values of overall city energy fluxes (Ward et. al., 2014).

Improving the valuation of urban tree ecosystem service provision

416 i-Tree Eco has been developed to help assess and manage urban tree populations for the benefits they 417 can provide (i-Tree, 2017). To this end, a primary function of the tool is to quantify and monetarise 418 environmental functions of the urban forest. The economic case for urban trees is stronger where a 419 more comprehensive range of the benefits are valued. The current i-Tree Eco (version 6) provides inter 420 alia an estimate of building energy use avoided based upon shade provision (summer time) and shelter 421 provision (winter time) that result in decreases in electricity and gas consumption for cooling and 422 heating, respectively. However the valuation is not fit-for-purpose internationally, where the model has 423 not been parameterised for different construction materials. The first of our two modelling approaches 424 is consistent with the i-Tree Eco approach with its calculation of leaf area according to urban forest 425 (species) composition and deferring to genus data where species specific values are not available. 426 However, as this approach is not a direct analogue of an anthropogenic service equivalent it's suitability 427 in natural capital accounting type situations should be further tested (Defra/ONS, 2017). 
Comparisons to $\mathrm{A} / \mathrm{C}$ units is limited since they are intended to cool air in enclosed buildings, not open air 430 environments. However, they are useful conceptually to provide a comparative monetary value for the 431 cooling service. The value produced here for the $E_{t}$ cooling potential of Inner London was $£ 84 \mathrm{~m} / \mathrm{annum}$. 432 In comparison, the building energy modelling provided a cost saving, directly attributable to the trees, of 433 between $£ 2.1 \mathrm{~m}$ and $£ 22.0 \mathrm{~m}$ annually (for Inner London) based upon the practical energy costs to 434 cooling indoor environments in the same situations. As such, a way to value a particular outcome of $E_{t}$ 435 has been explored and shown to be significant. The sophistication of the evaluation is currently limited 436 by its consideration of one hypothetical street scene, only. Modelling street canyons of varying size 437 more representative of the heterogeneity of a large city such as London and comparison to other 438 cityscapes needs to be tested prior to its application within or alongside a tool like i-Tree.

\section{Conclusion}

441 Evapotranspiration rate $\left(E_{t} R\right)$ data proved to be limited. New data collection on $g_{s}$ and $E_{t} R$ of different 442 tree species is required to improve understanding of the role of urban trees in cooling cities. Within 443 these limitations, the study showed that the range of cooling potential provides energy saving 444 associated with the sensible cooling load of buildings. The sensitivity to cooling regime (i.e. sensible 445 versus latent), simplifications in the modelling approach, and focus on $E_{t}$ effects demonstrate there is 446 more to be done to understand the full impact of urban forest on building energy saving use. Such work 447 must consider varying climatic conditions if the role of climate change and microclimatic effects are to 448 be understood. Furthermore, transferability of $E_{t}$ measures could be improved through the publication 449 of standard metrics of tree height, trunk diameter and canopy sizes, which were often missing from the 450 literature reviewed.

The case study results show that the amount of evapotranspirational cooling has substantial economic 453 value - in the order of $10^{6} \mathrm{E} /$ annum when calculated through comparison with a replacement service or 454 via direct impacting on building air-conditioning. Growing city populations, increased energy density and 455 projected climate change (IPCC, 2014) are already causing city authorities to plan the mitigation of and 456 adaptation to future heat stress. Including the assessment of $E_{t}$ cooling energy into tools such as $\mathrm{i}$-Tree 457 Eco could improve the effectiveness of urban tree planning and management under a changing climate. 458

\section{Acknowledgements}




\section{References}

463 Akbari, H., Pomerantz, M. and Taha, H. (2001). Cool surfaces and shade trees to reduce energy use and 464 improve air quality in urban areas. Solar Energy, 70(3), 295-310.

465 Akbari, H. (2002). Shade trees reduce building energy use and $\mathrm{CO}_{2}$ emissions from power plants. 466 Environmental Pollution, 116(1), S119-S126.

467 Amer, O., Boukhanouf, R. and Ibrahim, H. G. (2015). A Review of Evaporative Cooling Technologies. 468 Interantional Journal of Environmental Science and Development, 6(2), 111-117.

469 Antoniadis, C. N. and Martinopoulos, G. (2018). Optimization of a building integrated solar thermal 470 system with seasonal storage using TRNSYS. Renewable Energy, (In Press).

471 Arnfield, A. J. (2003). Two decades of urban climate research: A review of turbulence, exchanges of 472 energy and water, and the urban heat island. International Journal of Climatology, 23(1), 1-26.

473 Atkinson, C. J., Hipps, N. A., Davies, M. J., Dunn, J. and Griffiths, H. (2004). Controlling Water Use of 474 Trees to Alleviate Subsidence Risk. Horticulture LINK Project 212. BRE, UK. Ballinasa, M., Barradasa, V.L. 475 (2015). The Urban Tree as a Tool to Mitigate the Urban Heat Island in Mexico City: A Simple 476 Phenomenological Model. Special section: The Urban Forest and Ecosystem Services. J. of Environmental 477 Quality, doi:10.2134/jeq2015.01.0056.

478 BEIS (Department for Business, Energy \& Industrial Strategy). (2018). Statistical data set: Annual 479 480 481 domestic energy bills, file: Average annual domestic electricity bills by various consumption levels (QEP 2.2.5). Available online at: https://www.gov.uk/government/statistical-data-sets/annual-domesticenergy-price-statistics. Accessed 24 ${ }^{\text {th }}$ May 2018.

482 BEIS (Department for Business, Energy \& Industrial Strategy). (2017). Energy consumption in the UK. 483 Available online from: https://www.gov.uk/government/statistics/energy-consumption-in-the-uk Energy 484 consumption in the UK (ECUK) 2017 Data Tables: Table 1.04. Accessed 29th May 2018.

485 Belda, M., Holtanová, E., Halenka, T. and Kalvová, J. (2014). Climate classification revisited: From Köppen 486 to Trewartha. Climate Research, 59(1), 1-13.

487 Bernacchi, C. J., Leakey, A. D. B., Kimball, B. A. and Ort, D. R. (2011). Growth of soybean at future 488 tropospheric ozone concentrations decreases canopy evapotranspiration and soil water depletion. 489 Environmental Pollution, 159(6), 1464-1472.

490 Betson, M. and Scholefield, P. (2004). Review of the Evapotranspiration of Herbaceous and Afforested 491 Duneland Ecosystems, Anglesey, Wales. Wolverhampton, UK.

492 Bradley, D. E. and Utzinger, D. M. (2007). Enhancement and Use of Combined Simulation Tools in the 493 Assessment of Hybrid Natural/Mechanical Ventilation Systems. ASHRAE Transactions, 113(2) .

494 Breuer, L., Eckhardt, K. and Frede, H. G. (2003). Plant parameter values for models in temperate 495 climates. Ecological Modelling, 169(2-3), 237-293. 
BS/EN12977 (2018). Thermal solar systems and components - Custom built systems. London: British/European Standard.

498 Ca, V. T., Asaeda, T. and Abu, E. M. (1998). Reductions in air conditioning energy caused by a nearby 499 park. Energy and Buildings, 29(1), 83-92.

500 Ca, V. T., Asaeda, T. and Ashie, Y. (1999). Development of a numerical model for the evaluation of the 501 urban thermal environment. Journal of Wind Engineering and Industrial Aerodynamics, 81(1-3), 181502196.

503 Cóstola, D., Blocken, B. and Hensen, J. L. M. (2009). Overview of pressure coefficient data in building 504 energy simulation and airflow network programs. Building and Environment, 44(10), 2027-2036.

505 Davies, H.J., Doick, K.J., Handley, P., O'Brien, L. and Wilson, J. (2017). Delivery of Ecosystem Services by 506 Urban Forests. Forestry Commission Research Report 26. Forestry Commission, Edinburgh, 34pp.

507 Day, A. R., Jones, P. G. and Maidment, G. G. (2009). Forecasting future cooling demand in London. 508 Energy and Buildings, 41 (9), 942-948.

509 Defra/ONS (2017). Principles of Natural Capital Accounting. 510 https://www.ons.gov.uk/economy/environmentalaccounts/methodologies/principlesofnaturalcapitalac 511 counting

512 Doick, K.J., Hutchings, T.R. (2013). Air temperature regulation by urban trees and green infrastructure.

513 Research note 12 (FCRN012). Forestry Commission, Edinburgh, 10pp.

514 Eftec (2017). A study to scope and develop urban natural capital accounts for the UK. A report for Defra. 515 (June 2017). Eftec, London. 128pp. Available online from:

516 http://randd.defra.gov.uk/Document.aspx?Document=14143 UrbanNC Account FinalReportAugust201 $517 \quad$ 7.pdf. Accessed: 23rd May, 2018.

518 Fini, A., Ferrini, F., Frangi, P., Amoroso, G. and Piatti, R. (2009). Withholding irrigation during the 519 520 establishment phase affected growth and physiology of Norway maple (Acer platanoides) and linden (Tilla spp.). Arboriculture and Urban Forestry, 35 (5), 241-251.

Gerosa, G., Mereu, S., Finco, A. and Marzuoli, R. (2012). Stomatal Conductance Modeling to Estimate the Evapotranspiration of Natural and Agricultural Ecosystems. Chapter 18. In: Evapotranspiration - Remote Sensing and Modeling. Irmak, A. (Ed.). 403-420.

527

Gill, S. E., Handley, J. F., Ennos, A. R., Pauleit, S., Theuray, N. and Lindley, S. J. (2008). Characterising the urban environment of UK cities and towns: A template for landscape planning. Landscape and Urban Planning, 87(3), 210-222.

530 Gillner, S., Vogt, J., Tharang, A., Dettmann, S. and Roloff, A. (2015). Role of street trees in mitigating 531 effects of heat and drought at highly sealed urban sites. Landscape and Urban Planning, 143, 33-42. 
Grimmond, S. (2007). Urbanization and global environmental change: local effects of urban warming. 533 Geographical Journal, 173(1), 83-88.

534 Grosso, M. (1992). Wind pressure distribution around buildings: a parametrical model. Energy and 535 Buildings, 18(2), 101-131.

536 Health Protection Agency (2012). Health Effects of Climate Change in the UK 2012: Current evidence, 537 recommendations and research gaps. Health Protection Agency, London.

538 Heath, J. (1998). Stomata of trees growing in $\mathrm{CO}_{2}$-enriched air show reduced sensitivity to vapour 539 pressure deficit and drought. Plant, Cell and Environment, 21(11), 1077-1088.

540 Hipps, N. A., Davies, M. J., Dunn, J. M., Griffiths, H. and Atkinson, C. J. (2014). Effects of two contrasting 541 canopy manipulations on growth and water use of London plane (Platanus $x$ acerifolia) trees. Plant and 542 Soil, 382(1-2), 61-74.

543 Hsieh, C-M., Li, J-J., Zhang, L., Schwegler, B. (2018). Effects of tree shading and transpiration on building 544 cooling energy use. Energy and Buildings, 159, 382-397.

545 Hutchings, T., Lawrence, V. and Brunt, A. (2012). Estimating the Value of Ecosystem Services Value of 546 Edinburgh's Trees: Results of a 2011 Survey. Forest Research, Farnham. 45pp.

547 IPCC. (2014). Climate Change 2014 Synthesis Report. Contribution of Working Groups I, II and III to the 548 Fifth Assessment Report of the Intergovernmental Panel on Climate Change, 151pp.

549 i-Tree. (2017). What is i-Tree? Available online: www.itreetools.org. [Accessed: $3^{\text {rd }}$ July 2017].

550 Jenkins, D., Liu, Y. and Peacock, A. D. (2008). Climatic and internal factors affecting future UK office 551 heating and cooling energy consumptions. Energy and Buildings, 40(5), 874-881.

552 Kottek, M., Grieser, J., Beck, C., Rudolf, B. and Rubel, F. (2006). World map of the Köppen-Geiger climate 553 classification updated. Meteorologische Zeitschrift, 15(3), 259-263.

554 Kozlowski, T. T. and Pallardy, S. G. (1997). Physiology of Wood Plants. Second. Academic Press.

555 Kruijt, B., Witte, J. P. M., Jacobs, C. M. J. and Kroon, T. (2008). Effects of rising atmospheric CO2 on 556 evapotranspiration and soil moisture: A practical approach for the Netherlands. Journal of Hydrology, 557 349(3-4), 257-267.

558 Leuzinger, S., Vogt, R. and Körner, C. (2010). Tree surface temperature in an urban environment. 559 Agricultural and Forest Meteorology, 150 (1), 56-62.

560 Levermore, G. J. and Parkinson, J. B. (2006). Analyses and algorithms for new Test Reference Years and 561 Design Summer Years for the UK. Building Services Engineering Research and Technology, 27(4), 311562325.

563 Loridan, T. and Grimmond, C. S. B. (2012) Characterization of energy flux partitioning in urban 564 environments: links with surface seasonal properties. Journal of Applied Meteorology and Climatology, $56551(2), 219-241$. 
Loutzenhiser, P., Manz, H. and Maxwell, G. (2007). Empirical validations of shading/daylighting/load interactions in building energy simulation tools. Report for the International Energy Agency's SHC Task 34.

569 Masson, V., Marchadier, C., Adolphe, L., Aguejdad, R., Avner, P., Bonhomme, M., Bretagne, G., Briottet, 570 X., Bueno, B., de Munck, C., Doukari, O., Hallegatte, S., Hidalgo, J., Houet, T., Le Bras, J., Lemonsu, A., 571 Long, N., Moine, M. P., Morel, T., Nolorgues, L., Pigeon, G., Salagnac, J. L., Viguié, V. and Zibouche, K. 572 (2014). Adapting cities to climate change: A systemic modelling approach. Urban Climatology, 10, 407573429.

574 Mora, C., Dousset, B., Caldwell, I. R., Powell, F.E., Geronimo, R.C., Bielecki, C.R., Counsell, C.W.W, 575 Dietrich, B.S., Johnston, E.T., Louis, L.V., Lucas, M.P., McKenzie, M.M., Shea, A.G., Tseng, H., 576 Giambelluca, T.W., Leon, L.R., Hawkins E., Trauernicht, C. (2017). Global risk of deadly heat. Nature 577 Climate Change letters, 7(July), 501-506. DOI: 10.1038/NCLIMATE3322

578 579 580 581 582

Neymark, J., Judkoff, R., National Renewable Energy, and International Energy, A. (2008). International Energy Agency Building Energy Simulation Test and Diagnostic Method (IEA BESTEST): multi-zone nonairflow in-depth diagnostic cases: MZ320 - MZ360.Nowak, D. and Crane, D. (1998). The urban forest effects (UFORE) model: quantifying urban forest structure and function. Integrated Tools Proceedings, 714-720.

Peters, E.B., McFadden, J.P., Montgomery, R.A. (2010). Biological and environmental controls on tree transpiration in a suburban landscape. Journal of Geophysical Research, Biogeosciences, 115:G04006.

Rahman, M. A., Armson, D. and Ennos, A. R. (2015). A comparison of the growth and cooling effectiveness of five commonly planted urban tree species. Urban Ecosystems, 18, 371-389.

Rahman, M.A., Moser, A., Gold, A., Rötzer, T., Pauleit, S. (2018) Vertical air temperature gradients under the shade of two contrasting urban tree species during different types of summer days. Science of the Total Environment, 633, 100-111.

Rahman, M. A., Smith, J. G., Stringer, P. and Ennos, A. R. (2011). Effect of rooting conditions on the growth and cooling ability of Pyrus calleryana. Urban Forestry and Urban Greening, 10(3), 185-192.

Reid, W. V., Mooney, H. A., Cropper, A., Capistrano, D., Carpenter, S. R., Chopra, K., Dasgupta, P., Dietz, T., Duraiappah, A. K., Hassan, R., Kasperson, R., Leemans, R., May, R. M., McMichael, T. A. J., Pingali, P., Samper, C., Scholes, R., Watson, R. T., Zakri, A. H., Shidong, Z., Ash, N. J., Bennett, E., Kumar, P., Lee, M. J., Raudsepp-Hearne, C., Simons, H., Thonell, J. and Zurek, M. B. (2005). Ecosystems and human wellbeing: Synthesis. Sarukhán, J. and Whyte, A. (eds.). Island Press.

Rogers, K., Sacre, K., Goodenough, J. and Doick, K. (2015). Valuing London's Urban Forest. Treeconomics, London. 82pp.

Rumble, H., Rogers, K., Doick, K., Albertini, A. and Hutchings, T. (2015). Valuing Wrexham's Urban Forest - assessing the ecosystem services of Wrexham's urban forest. Forest Research, Farnham. 45pp.

Saaroni, H., Amorim, J.H., Hiemstra, J.A., Pearlmutter, D. (2018). Urban Green Infrastructure as a tool for urban heat mitigation: Survey of research methodologies and findings across different climatic regions. Urban Climate, 24, 94-110. 
Santamouris, M. (2013). The Role of Green Spaces. In: Energy and Climate in the Urban Built Environment, Routledge.

606 Shahrestani, M., Yao, R. and Cook, G. K. (2013). Characterising the energy performance of centralised 607 HVAC\&R systems in the UK. Energy and Buildings, 62, 239-247.

608 Shahrestani, M., Yao, R., Essah, E., Shao, L., Oliveira, A. C., Hepbasli, A., Biyik, E., Caño, T. d., Rico, E. and 609 Lechón, J. L. (2017). Experimental and numerical studies to assess the energy performance of naturally 610 ventilated PV façade systems. Solar Energy, 147, 37-51.

611 Smithers, R.J., Doick, K.J., Burton, A., Sibille, R., Steinbach, D., Harris, R., Groves, L., Blicharska, M. (2018). 612 Comparing the relative abilities of tree species to cool the urban environment. Urban Ecosystems.

613 (May), 1-12.

614 Stratópoulos, L.M.F., Duthweiler, S., Häberle, K.-H., Pauleit, S. (2018). Effect of native habitat on the 615 cooling ability of six nursery-grown tree species and cultivars for future roadside plantings. Forestry and 616 Urban Greening, 30, 37-45.

617 Stritih, U., Charvat, P., Koželj, R., Klimes, L., Osterman, E., Ostry, M. and Butala, V. (2018). PCM thermal 618 energy storage in solar heating of ventilation air: Experimental and numerical investigations. Sustainable 619 Cities and Society, 37, 104-115.

620 Taha, H. (1997). Urban climates and heat islands: albedo, evapotranspiration, and anthropogenic heat. 621 Energy and Buildings, 25(2), 99-103.

622 TRNFLOW. (2009). A module of an air flow network for coupled simulation-manual. Stuttgart: Transsolar 623 Energietechnik.

624 TRNSYS. (2010). TRNSYS 17: a transient system simulation program. Wisconsin: Solar Energy Laboratory, 625 University of Wisconsin.

626 UFWACN. (2015). Our Vision for Our Urban Forest. Urban Forestry and Woodlands Advisory Committees 627 Network, p.1-15. Available online: https://www.forestry.gov.uk/urbanforestry. Accessed 23rd May 2018.

628 UFWACN. (2016). Introducing England's urban forests: Definition, distribution, composition and 629 benefits. UFWACN (Urban Forestry and Woodlands Advisory Committees (FWAC) Network), 14pp. 630 Available online from: https://www.forestry.gov.uk/urbanforestry. Accessed $23^{\text {rd }}$ May 2018.

631 United Nations et al., (2012). System of Environmental-Economic Accounting: Central Framework. 632 Available online: http://unstats.un.org/unsd/envaccounting/White cover.pdf

633 Varghese, J. T., Ghosh, S., Pandey, S. and Samanta, R. (2015). Evaluating the cleansing efficiency of an 634 extended living façade draped with vernonia elaegnifolia. Journal of Green Building, 10, 157-177.

635 Wagner, W. and Pruss, A. (2002). The IAPWS Formulation 1995 for the Thermodynamic Properties of 636 Ordinary Water Substance for General and Scientific Use. Journal of Physical and Chemical Reference 637 Data, 31(2), 387-535.

638 Ward, H. C., Evans, J. G. and Grimmond, C. S. B. (2014) Multi-scale sensible heat fluxes in the urban 639 environment from large aperture scintillometry and eddy covariance. Boundary- Layer Meteorology, 152 
$640 \quad(1), 65-89$.

1181

1182

1183

641 Wullschleger, S. D., Meinzer, F. C. and Vertessy, R. A. (1998). A Review of Whole-Plant Water Use Studies 642 in Tree. Tree Physiology, 18(8-9), 499-512.

1184

1185

1186

1187

1188

1189

1190

1191

1192

1193

1194

1195

1196

1197

1198

1199

1200

1201

1202

1203

1204

1205

1206

1207

1208

1209

1210

1211

1212

1213

1214

1215

1216

1217

1218

1219

1220

1221

1222

1223

1224

1225

1226

1227

1228

1229

1230

1231

1232 
643 Table 1 - Evapotranspiration rates for tree species taken from literature. "spp." used to indicate where

644 species not specified. Underlined values calculated from the reported stomatal conductance values.

645 (References are: ${ }^{1}$.Heath, 1998; ${ }^{2}$.Wullschleger et al., 1998; ${ }^{3} \cdot$ Breuer et al., 2003; ${ }^{4}$.Atkinson et al., 2004;

646 5. Betson and Scholefield, 2004; ${ }^{6} \cdot$ Fini et al., 2009; 7.'Leuzinger et al., 2010; ${ }^{8}$.Hipps et al., 2014; 9.Rahman

647 et al., 2015; ${ }^{10}$.Gillner et al., 2015).

648

\begin{tabular}{|c|c|c|c|c|c|c|c|c|c|}
\hline $\begin{array}{l}\text { Common } \\
\text { Name }\end{array}$ & Scientific Name & $\begin{array}{l}\text { Experiment } \\
\text { Conditions }\end{array}$ & $\begin{array}{c}\text { Age } \\
\text { (years) }\end{array}$ & $\begin{array}{l}\text { Height } \\
\text { (m) }\end{array}$ & $\begin{array}{l}\mathrm{DBH}^{*} \\
(\mathrm{~cm})\end{array}$ & $\begin{array}{c}E_{t} \min \\
\left(g^{-2} s^{-1}\right)\end{array}$ & $\begin{array}{c}E_{t} \max \\
\left(\mathrm{g} \mathrm{m}^{-2} \mathrm{~s}^{-1}\right)\end{array}$ & $\begin{array}{l}\text { Mean } E_{t} \\
\left(\mathrm{~g} \mathrm{~m}^{-2} \mathrm{~s}^{-1}\right)\end{array}$ & $\begin{array}{c}\begin{array}{c}\text { Genus } E_{t} \\
\text { (Mean) }\end{array} \\
\left(\mathrm{g} \mathrm{m}^{-2} \mathrm{~s}^{-1}\right)\end{array}$ \\
\hline $\begin{array}{l}\text { Norway } \\
\text { Maple }^{6,7}\end{array}$ & $\begin{array}{c}\text { Acer } \\
\text { platanoides }\end{array}$ & Irrigated & $\mathrm{n} / \mathrm{a}$ & $\mathrm{n} / \mathrm{a}$ & 3.5 & $\underline{0.034}$ & $\underline{0.075}$ & $\underline{0.053}$ & \multirow[t]{2}{*}{0.037} \\
\hline Red Maple ${ }^{2}$ & Acer rubrum & $\mathrm{n} / \mathrm{a}$ & $\mathrm{n} / \mathrm{a}$ & $\mathrm{n} / \mathrm{a}$ & $\mathrm{n} / \mathrm{a}$ & $\underline{0.021}$ & $\underline{0.021}$ & $\underline{0.021}$ & \\
\hline $\begin{array}{c}\text { Red Horse } \\
\text { Chestnut }^{7,10}\end{array}$ & $\begin{array}{c}\text { Aesculus } \times \\
\text { carnea Hayne }\end{array}$ & $n / a$ & 15 & 9.2 & 20.75 & $\underline{0.009}$ & $\underline{0.009}$ & $\underline{0.009}$ & \multirow{3}{*}{0.032} \\
\hline $\begin{array}{c}\text { Horse } \\
\text { Chestnut }^{7}\end{array}$ & $\begin{array}{c}\text { Aesculus } \\
\text { hippocastanum }\end{array}$ & $n / a$ & $n / a$ & $\mathrm{n} / \mathrm{a}$ & $\mathrm{n} / \mathrm{a}$ & $\underline{0.053}$ & $\underline{0.053}$ & $\underline{0.053}$ & \\
\hline Chestnut spp. ${ }^{1}$ & Aesculus spp. & $\begin{array}{c}\text { In Ambient } \\
\text { Air }\end{array}$ & 2 & $\mathrm{n} / \mathrm{a}$ & $n / a$ & $\underline{0.029}$ & $\underline{0.041}$ & $\underline{0.035}$ & \\
\hline $\begin{array}{l}\text { Turkish } \\
\text { Hazel }^{10}\end{array}$ & $\begin{array}{c}\text { Corylus corluna } \\
\text { L. }\end{array}$ & $\mathrm{n} / \mathrm{a}$ & 13 & 8.5 & 15.75 & $\underline{0.034}$ & $\underline{0.034}$ & $\underline{0.034}$ & 0.034 \\
\hline $\begin{array}{l}\text { Midland } \\
\text { Hawthorn? }\end{array}$ & $\begin{array}{l}\text { Crataegus } \\
\text { laevigata }\end{array}$ & $\mathrm{n} / \mathrm{a}$ & $\mathrm{n} / \mathrm{a}$ & 6 & 1.37 & $\underline{0.074}$ & $\underline{0.089}$ & $\underline{0.081}$ & 0.081 \\
\hline Beech spp. ${ }^{1}$ & Fagus spp. & $\begin{array}{c}\text { In Ambient } \\
\text { Air }\end{array}$ & 2 & $\mathrm{n} / \mathrm{a}$ & $\mathrm{n} / \mathrm{a}$ & $\underline{0.035}$ & $\underline{0.045}$ & $\underline{0.040}$ & \multirow{2}{*}{0.039} \\
\hline $\begin{array}{c}\text { Common } \\
\text { Beech }^{2}\end{array}$ & Fagus sylvatica & $\begin{array}{l}100-y r-o l d \\
\text { plantation }\end{array}$ & $\mathrm{n} / \mathrm{a}$ & 35 & 54 & $\underline{0.039}$ & $\underline{0.039}$ & $\underline{0.039}$ & \\
\hline Red Beech² & $\begin{array}{l}\text { Nothofagus } \\
\text { fusca }\end{array}$ & $\begin{array}{l}\text { Pristine } \\
\text { forest }\end{array}$ & $n / a$ & 34 & 60 & $\underline{0.077}$ & $\underline{0.077}$ & $\underline{0.077}$ & 0.077 \\
\hline $\begin{array}{l}\text { Maidenhair } \\
\text { Tree }^{10}\end{array}$ & $\begin{array}{c}\text { Ginkgo biloba } \\
\text { L. }\end{array}$ & $n / a$ & 19 & 12.6 & 25.5 & $\underline{0.014}$ & $\underline{0.014}$ & $\underline{0.014}$ & 0.014 \\
\hline Tulip Tree $^{10}$ & $\begin{array}{l}\text { Liriodendron } \\
\text { tulipifera L. }\end{array}$ & $\mathrm{n} / \mathrm{a}$ & 14 & 10.65 & 19.75 & $\underline{0.004}$ & $\underline{0.004}$ & $\underline{0.004}$ & 0.004 \\
\hline $\begin{array}{c}\text { Crabapple } \\
\text { Tree }^{9}\end{array}$ & $\begin{array}{c}\text { Malus } \\
\text { 'Rudolph' }\end{array}$ & $\mathrm{n} / \mathrm{a}$ & $\mathrm{n} / \mathrm{a}$ & 6 & 1.37 & $\underline{0.046}$ & $\underline{0.077}$ & $\underline{0.062}$ & \multirow{2}{*}{0.062} \\
\hline $\begin{array}{l}\text { Common } \\
\text { Apple }^{3}\end{array}$ & $\begin{array}{c}\text { Malus } \\
\text { domestica }\end{array}$ & $\mathrm{n} / \mathrm{a}$ & 9 & $\mathrm{n} / \mathrm{a}$ & $\mathrm{n} / \mathrm{a}$ & $\underline{0.063}$ & $\underline{0.063}$ & $\underline{0.063}$ & \\
\hline Sitka Spruce ${ }^{3}$ & Picea sitchensis & $\mathrm{n} / \mathrm{a}$ & $\mathrm{n} / \mathrm{a}$ & 11.5 & $\mathrm{n} / \mathrm{a}$ & $\underline{0.044}$ & $\underline{0.044}$ & $\underline{0.044}$ & 0.044 \\
\hline Corsican Pine 5 & Pinus nigra & Forest & $\mathrm{n} / \mathrm{a}$ & 15 & $\mathrm{n} / \mathrm{a}$ & $\underline{0.040}$ & $\underline{0.040}$ & $\underline{0.040}$ & \multirow{2}{*}{0.030} \\
\hline Cluster Pine ${ }^{2}$ & Pinus pinaster & $\mathrm{n} / \mathrm{a}$ & $\mathrm{n} / \mathrm{a}$ & 20 & 34 & $\underline{0.019}$ & $\underline{0.019}$ & $\underline{0.019}$ & \\
\hline $\begin{array}{l}\text { London } \\
\text { Plane }{ }^{3,7}\end{array}$ & $\begin{array}{l}\text { Platanus } \\
\text { acerifolia }\end{array}$ & $\begin{array}{c}\text { fully } \\
\text { expanded } \\
\text { leaves }\end{array}$ & 28 & 20 & $\mathrm{n} / \mathrm{a}$ & $\underline{0.031}$ & $\underline{0.096}$ & $\underline{0.063}$ & 0.063 \\
\hline
\end{tabular}




\begin{tabular}{|c|c|c|c|c|c|c|c|c|c|}
\hline $\begin{array}{l}\text { Common } \\
\text { Name }\end{array}$ & Scientific Name & $\begin{array}{l}\text { Experiment } \\
\text { Conditions }\end{array}$ & $\begin{array}{c}\text { Age } \\
\text { (years) }\end{array}$ & $\begin{array}{c}\text { Height } \\
(\mathrm{m})\end{array}$ & $\begin{array}{l}\mathrm{DBH}^{*} \\
(\mathrm{~cm})\end{array}$ & $\begin{array}{c}E_{t} \min \\
\left(g^{-2} \mathrm{~s}^{-1}\right)\end{array}$ & $\begin{array}{c}E_{t} \max \\
\left(\mathrm{g} \mathrm{m}^{-2} \mathrm{~s}^{-1}\right)\end{array}$ & $\begin{array}{l}\text { Mean } E_{t} \\
\left(\mathrm{~g} \mathrm{~m}^{-2} \mathrm{~s}^{-1}\right)\end{array}$ & $\begin{array}{c}\text { Genus } E_{t} \\
\text { (Mean) } \\
\left(g^{-2} \mathrm{~s}^{-1}\right)\end{array}$ \\
\hline $\begin{array}{c}\text { Black } \\
\text { Cottonwood }{ }^{2}\end{array}$ & $\begin{array}{c}\text { Populus } \\
\text { trichocarpa }\end{array}$ & $\mathrm{n} / \mathrm{a}$ & $\mathrm{n} / \mathrm{a}$ & 15 & 15 & $\underline{0.120}$ & $\underline{0.120}$ & $\underline{0.120}$ & 0.120 \\
\hline $\begin{array}{l}\text { Umineko } \\
\text { Cherry } \\
\text { Blossom } 9\end{array}$ & $\begin{array}{l}\text { Prunus } \\
\text { 'Umineko' }\end{array}$ & $\mathrm{n} / \mathrm{a}$ & $\mathrm{n} / \mathrm{a}$ & 6 & 1.37 & $\underline{0.070}$ & $\underline{0.085}$ & $\underline{0.077}$ & \multirow[t]{2}{*}{0.063} \\
\hline Cherry spp. ${ }^{4}$ & Prunus spp. & wild & $n / a$ & $\mathrm{n} / \mathrm{a}$ & $\mathrm{n} / \mathrm{a}$ & $\underline{0.048}$ & $\underline{0.048}$ & 0.048 & \\
\hline Callery pear ${ }^{9}$ & $\begin{array}{c}\text { Pyrus } \\
\text { calleryana }\end{array}$ & $\mathrm{n} / \mathrm{a}$ & $\mathrm{n} / \mathrm{a}$ & 6 & 1.37 & $\underline{0.097}$ & $\underline{0.155}$ & $\underline{0.126}$ & 0.126 \\
\hline Oak spp. ${ }^{1}$ & Quercus spp. & $\begin{array}{c}\text { In Ambient } \\
\text { Air }\end{array}$ & 2 & $\mathrm{n} / \mathrm{a}$ & $\mathrm{n} / \mathrm{a}$ & $\underline{0.041}$ & $\underline{0.058}$ & $\underline{0.049}$ & 0.049 \\
\hline $\begin{array}{c}\text { Mountain } \\
\text { Ash }^{9}\end{array}$ & $\begin{array}{c}\text { Sorbus } \\
\text { arnoldiana }\end{array}$ & $\mathrm{n} / \mathrm{a}$ & $\mathrm{n} / \mathrm{a}$ & 6 & 1.37 & $\underline{0.074}$ & $\underline{0.076}$ & $\underline{0.075}$ & 0.075 \\
\hline $\begin{array}{c}\text { Small leaved } \\
\text { lime }^{6,7,10}\end{array}$ & Tilia cordata & Irrigated & $\mathrm{n} / \mathrm{a}$ & n/a & 3.5 & 0.031 & 0.075 & 0.057 & \multirow{4}{*}{0.053} \\
\hline $\begin{array}{c}\text { Broad leaved } \\
\text { lime }^{6,7}\end{array}$ & $\begin{array}{c}\text { Tilia } \\
\text { platyphyllos }\end{array}$ & Irrigated & $\mathrm{n} / \mathrm{a}$ & $\mathrm{n} / \mathrm{a}$ & 3.5 & 0.023 & 0.054 & 0.041 & \\
\hline Silver lime $e^{6,7}$ & Tilia tomentosa & Irrigated & $\mathrm{n} / \mathrm{a}$ & $\mathrm{n} / \mathrm{a}$ & 3.5 & 0.040 & 0.086 & 0.061 & \\
\hline $\begin{array}{l}\text { Common } \\
\text { lime }^{6}\end{array}$ & Tilia $x$ europaea & Irrigated & $\mathrm{n} / \mathrm{a}$ & $\mathrm{n} / \mathrm{a}$ & 3.5 & 0.028 & 0.075 & 0.052 & \\
\hline Dutch Elm ${ }^{10}$ & \begin{tabular}{|c|} 
Ulmus $x$ \\
hollandica Mill. \\
'Lobel'
\end{tabular} & $\mathrm{n} / \mathrm{a}$ & 14 & 12.88 & 23.5 & $\underline{0.023}$ & $\underline{0.023}$ & $\underline{0.023}$ & 0.023 \\
\hline \multicolumn{9}{|c|}{$E_{t}$ average (all genera): } & 0.054 \\
\hline
\end{tabular}

* DBH: diameter at breast height 
651 Table 2. The three most common tree species and the three most important species for delivering $E_{t}$ 652 cooling in each of the urban forest case studies.

\section{3}

\begin{tabular}{|c|c|c|c|c|c|}
\hline & & Edinburgh & Inner London & Outer London & Wrexham \\
\hline $\begin{array}{c}\text { Most } \\
\text { common } \\
\text { species }\end{array}$ & $1^{\text {st }}$ & Acer pseudoplatanus & Betula spp. & Acer pseudoplatanus & Acer pseudoplatanus \\
\cline { 2 - 6 } & $2^{\text {nd }}$ & Ilex aquifolium & Tilia x vulgaris & Quercus robur & Crataegus monogyna \\
\hline & $3^{\text {rd }}$ & Betula pendula & Magnolia spp. & Crataegus pedicellata & Betula pendula \\
\hline $\begin{array}{c}\text { Top } \mathrm{E}_{\mathrm{t}} \\
\text { providers }\end{array}$ & $1^{\text {st }}$ & Castanea sativa & $\begin{array}{c}\text { Platanus } \\
\text { hybrid }\end{array}$ & Castanea sativa & Platanus hybrida \\
\cline { 2 - 7 } & $2^{\text {nd }}$ & Acer platanoides & $\begin{array}{c}\text { Quercus } \\
\text { petraea }\end{array}$ & Crataegus monogyna & Fagus sylvatica \\
\cline { 2 - 7 } & $3^{\text {rd }}$ & Prunus avium & Prunus avium & Populus spp & Castanea sativa \\
\hline
\end{tabular}


655 Table 3. Evapotranspiration across the three case study urban forests.

\begin{tabular}{|c|c|c|c|c|c|c|}
\hline City & $\begin{array}{c}\text { Area size } \\
\left(\mathrm{km}^{2}\right)\end{array}$ & $\begin{array}{c}\text { Number of } \\
\text { trees } \\
\left(000^{\prime} \mathrm{s}\right)\end{array}$ & $\begin{array}{c}\text { Total leaf } \\
\text { area } \\
\left.\left(\mathrm{km}^{2}\right)(00)^{\prime} \mathrm{s}\right)\end{array}$ & $\begin{array}{c}\text { Total } \mathrm{E}_{\mathrm{t}} \\
\left(\mathrm{kg} \mathrm{s}^{-1}\right)\end{array}$ & $\begin{array}{c}\text { Mean } \mathrm{E}_{\mathrm{t}} \\
\text { per leaf } \\
\text { area } \\
\left(\mathrm{kg} \mathrm{s}^{-1} \mathrm{~km}^{-2}\right)\end{array}$ & $\begin{array}{c}\text { Mean } \mathrm{E}_{\mathrm{t}} \text { per } \\
\text { tree } \\
\left(\mathrm{kg} \mathrm{h}^{-1} \mathrm{tree}^{-1}\right)\end{array}$ \\
\hline Edinburgh & 115 & 638 & 74 & 3,500 & 47.4 & 19.8 \\
\hline Inner London & 310 & 1,587 & 217 & 11,700 & 53.9 & 26.5 \\
\hline Outer London & 1,285 & 6,807 & 1,047 & 44,900 & 54.1 & 23.7 \\
\hline Wrexham & 38 & 364 & 29 & 1,420 & 48.9 & 14.0 \\
\hline
\end{tabular}

\section{6}


658 Table 4. Summary of the estimated value of the effective cooling from each urban forest case study.

\begin{tabular}{|c|c|c|c|c|c|c|}
\hline \multirow[t]{2}{*}{ City } & Adjusted total q & $\begin{array}{c}\mathrm{A} / \mathrm{C} \text { unit* } \\
\text { equivalents }\end{array}$ & $\begin{array}{l}\text { Cooling } \\
\text { Value† }\end{array}$ & Average q & $\begin{array}{l}\mathrm{A} / \mathrm{C} \text { unit* } \\
\text { equivalents }\end{array}$ & Cooling value \\
\hline & $(\mathrm{MW})$ & (000's) & $\left(\mathrm{k} £ \mathrm{hr}^{-1}\right)$ & $\left(\mathrm{kW}\right.$ tree $\left.^{-1}\right)$ & $\left(\right.$ tree $\left.^{-1}\right)$ & $\left(£ \mathrm{hr}^{-1}\right.$ tree $\left.^{-1}\right)$ \\
\hline Edinburgh & $4,290( \pm 1,300)$ & 123 & $26( \pm 8)$ & $6.7( \pm 2.0)$ & 0.2 & $\pm 0.04( \pm 0.01)$ \\
\hline Inner London & $14,400( \pm 4,300)$ & 411 & $86( \pm 25)$ & $9.1( \pm 2.7)$ & 0.3 & $£ 0.05( \pm 0.02)$ \\
\hline Outer London & $55,200( \pm 16,000)$ & 1,580 & $329( \pm 97)$ & $8.1( \pm 2.4)$ & 0.2 & $£ 0.05( \pm 0.01)$ \\
\hline Wrexham & $1,740( \pm 510)$ & 50 & $10( \pm 3)$ & $4.8( \pm 1.4)$ & 0.1 & $£ 0.03( \pm 0.01)$ \\
\hline \multicolumn{7}{|c|}{ *based on $1.5 \mathrm{~kW}$ evaporative cooler (EcoCooling Ltd). } \\
\hline \multicolumn{7}{|c|}{ tat the 2017 UK Average rate of $0.14 \mathrm{f} / \mathrm{kWh}$ (BEIS, 2018) } \\
\hline
\end{tabular}


661 Table 5: Total cooling (and energy demand for cooling) supplied to a single building with and without 662 tree $\mathrm{E}_{\mathrm{t}}$ cooling applied and for different relative humidity $(\mathrm{RH})$ control set points.

\begin{tabular}{|l|c|c|c|c|c|c|}
\hline \multirow{3}{*}{ Description } & \multicolumn{5}{|c|}{ Cumulative cooling (and energy) demand $\mathrm{MWh}$} \\
\cline { 2 - 7 } & \multicolumn{4}{|c|}{ Indoor $\mathrm{RH}=50 \%$} & \multicolumn{3}{c|}{ Indoor $\mathrm{RH}=60 \%$} \\
\cline { 2 - 7 } & $\mathrm{E}_{\mathrm{t}}=0.015$ & $\mathrm{E}_{\mathrm{t}}=0.055$ & $\mathrm{E}_{\mathrm{t}}=0.165$ & $\mathrm{E}_{\mathrm{t}}=0.015$ & $\mathrm{E}_{\mathrm{t}}=0.055$ & $\mathrm{E}_{\mathrm{t}}=0.165$ \\
\hline With trees & $\begin{array}{c}6.68 \\
(3.34)\end{array}$ & $\begin{array}{c}6.65 \\
(3.33)\end{array}$ & $\begin{array}{c}6.57 \\
(3.29)\end{array}$ & $\begin{array}{c}5.51 \\
(2.75)\end{array}$ & $\begin{array}{c}5.47 \\
(2.74)\end{array}$ & $\begin{array}{c}5.37 \\
(2.68)\end{array}$ \\
\hline Without trees & $\begin{array}{c}6.69 \\
(3.35)\end{array}$ & $\begin{array}{c}6.69 \\
(3.35)\end{array}$ & $\begin{array}{c}6.69 \\
(3.35)\end{array}$ & $\begin{array}{c}5.52 \\
(2.76)\end{array}$ & $\begin{array}{c}5.52 \\
(2.76)\end{array}$ & $\begin{array}{c}5.52 \\
(2.76)\end{array}$ \\
\hline $\begin{array}{l}\text { Cooling demand } \\
\text { reduction (summer) }\end{array}$ & $0.15 \%$ & $0.60 \%$ & $1.82 \%$ & $0.24 \%$ & $0.92 \%$ & $2.73 \%$ \\
\hline
\end{tabular}


666 Table 6. Changes in cooling (and energy) demand with and without trees in the street canyon model 667 scenario, over the one-year modelling period for a range of $E_{t}$ values and relative humidity (RH) set668 points of $50 \%$ and $60 \%$ (based upon a $\mathrm{CoP}=2$ ).

669

\begin{tabular}{|c|c|c|c|c|c|c|c|c|c|c|c|c|}
\hline \multirow{3}{*}{ Description } & \multicolumn{12}{|c|}{$\begin{array}{l}\text { Cumulative cooling (and energy) demand MWh } \\
\text { Indoor } \mathrm{RH}=50 \%\end{array}$} \\
\hline & \multicolumn{4}{|c|}{$E_{t}=0.015$} & \multicolumn{4}{|c|}{$E_{t}=0.055$} & \multicolumn{4}{|c|}{$E_{t}=0.165$} \\
\hline & $\begin{array}{l}\text { Eva } \\
\text { Clg* }\end{array}$ & Sensible & Latent & Total & Eva Clg & Sensible & latent & Total & Eva Clg & Sensible & latent & Total \\
\hline With trees & \begin{tabular}{|c|}
51.6 \\
$(25.8)$ \\
\end{tabular} & \begin{tabular}{|c|}
291.7 \\
$(145.9)$ \\
\end{tabular} & \begin{tabular}{|l|}
129.2 \\
$(64.6)$ \\
\end{tabular} & $\begin{array}{c}420.9 \\
(210.5) \\
\end{array}$ & \begin{tabular}{|l|}
177.3 \\
$(88.7)$ \\
\end{tabular} & $\begin{array}{c}278.2 \\
(139.1) \\
\end{array}$ & $\begin{array}{l}144.9 \\
(72.5) \\
\end{array}$ & $\begin{array}{c}423.1 \\
(211.6) \\
\end{array}$ & $\begin{array}{c}532.1 \\
(266.0) \\
\end{array}$ & $\begin{array}{c}255.8 \\
(127.9) \\
\end{array}$ & \begin{tabular}{|l|}
169.6 \\
$(84.8)$ \\
\end{tabular} & $\begin{array}{c}425.4 \\
(212.7) \\
\end{array}$ \\
\hline Without trees & 0 & $\begin{array}{c}295.5 \\
(147.7) \\
\end{array}$ & \begin{tabular}{|l|}
125.1 \\
$(62.5)$ \\
\end{tabular} & $\begin{array}{c}420.6 \\
(210.2) \\
\end{array}$ & 0 & $\begin{array}{c}295.5 \\
(147.7) \\
\end{array}$ & \begin{tabular}{|l|}
125.1 \\
$(62.5)$ \\
\end{tabular} & $\begin{array}{c}420.6 \\
(210.3) \\
\end{array}$ & 0 & $\begin{array}{c}295.5 \\
(147.7) \\
\end{array}$ & \begin{tabular}{|l|}
125.1 \\
$(62.5)$ \\
\end{tabular} & $\begin{array}{r}420.6 \\
(210.3) \\
\end{array}$ \\
\hline $\begin{array}{l}\% \text { change in } \\
\text { demand }\end{array}$ & & $-1.28 \%$ & $3.30 \%$ & $0.09 \%$ & & $-5.85 \%$ & $15.9 \%$ & $0.61 \%$ & & $-13.4 \%$ & $35.6 \%$ & $1.15 \%$ \\
\hline \multirow{3}{*}{ Description } & \multicolumn{12}{|c|}{$\begin{array}{l}\text { Cumulative cooling (and energy) demand MWh } \\
\text { Indoor } \mathrm{RH}=60 \%\end{array}$} \\
\hline & \multicolumn{4}{|c|}{$E_{t}=0.015$} & \multicolumn{4}{|c|}{$E_{t}=0.055$} & \multicolumn{4}{|c|}{$E_{t}=0.165$} \\
\hline & Eva Clg & Sensible & Latent & Total & Eva Clg & Sensible & latent & Total & Eva Clg & Sensible & latent & Total \\
\hline With trees & \begin{tabular}{|c|}
51.6 \\
$(25.8)$ \\
\end{tabular} & \begin{tabular}{|c|}
291.7 \\
$(145.9)$ \\
\end{tabular} & \begin{tabular}{|c|}
58.3 \\
$(29.2)$ \\
\end{tabular} & $\begin{array}{c}350.0 \\
(175.0) \\
\end{array}$ & \begin{tabular}{|l|}
177.3 \\
$(88.7)$ \\
\end{tabular} & $\begin{array}{c}278.2 \\
(139.1) \\
\end{array}$ & $\begin{array}{c}68.0 \\
(34.0) \\
\end{array}$ & $\begin{array}{c}346.1 \\
(173.1)\end{array}$ & \begin{tabular}{|c|}
532.1 \\
$(266.0)$ \\
\end{tabular} & $\begin{array}{c}255.8 \\
(127.9) \\
\end{array}$ & \begin{tabular}{|c|}
84.4 \\
$(42.2)$ \\
\end{tabular} & $\begin{array}{c}340.2 \\
(170.1) \\
\end{array}$ \\
\hline Without trees & 0 & \begin{tabular}{|c|}
295.5 \\
$(147.7)$ \\
\end{tabular} & \begin{tabular}{|c|}
55.6 \\
$(27.8)$ \\
\end{tabular} & $\begin{array}{c}351.0 \\
(175.6) \\
\end{array}$ & 0 & $\begin{array}{c}295.5 \\
(147.7) \\
\end{array}$ & $\begin{array}{c}55.6 \\
(27.8) \\
\end{array}$ & $\begin{array}{c}351.0 \\
(175.5) \\
\end{array}$ & 0 & $\begin{array}{c}295.5 \\
(147.7) \\
\end{array}$ & \begin{tabular}{|c|}
55.6 \\
$(27.8)$ \\
\end{tabular} & $\begin{array}{r}351.0 \\
(175.5) \\
\end{array}$ \\
\hline $\begin{array}{l}\text { \% change in } \\
\text { demand }\end{array}$ & & $-1.28 \%$ & $4.95 \%$ & $-0.29 \%$ & & $-5.85 \%$ & $22.4 \%$ & $-1.39 \%$ & & $-13.4 \%$ & $52.0 \%$ & $-3.09 \%$ \\
\hline
\end{tabular}

670

$671 \quad *$ Eva Clg: evaporative cooling

672 

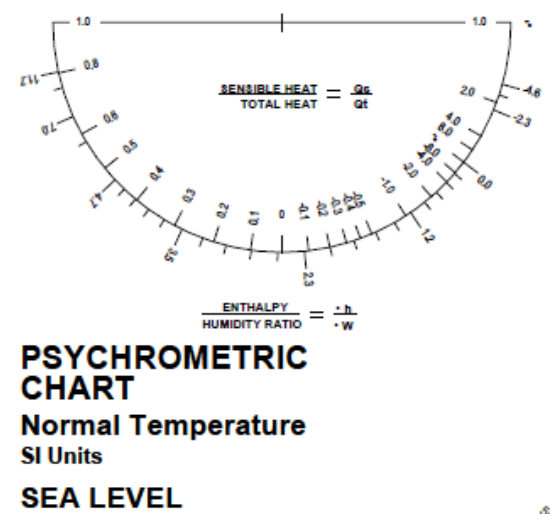

SEA LEVEL
BAROMETRIC PRESSURE: $101.325 \mathrm{kPa}$
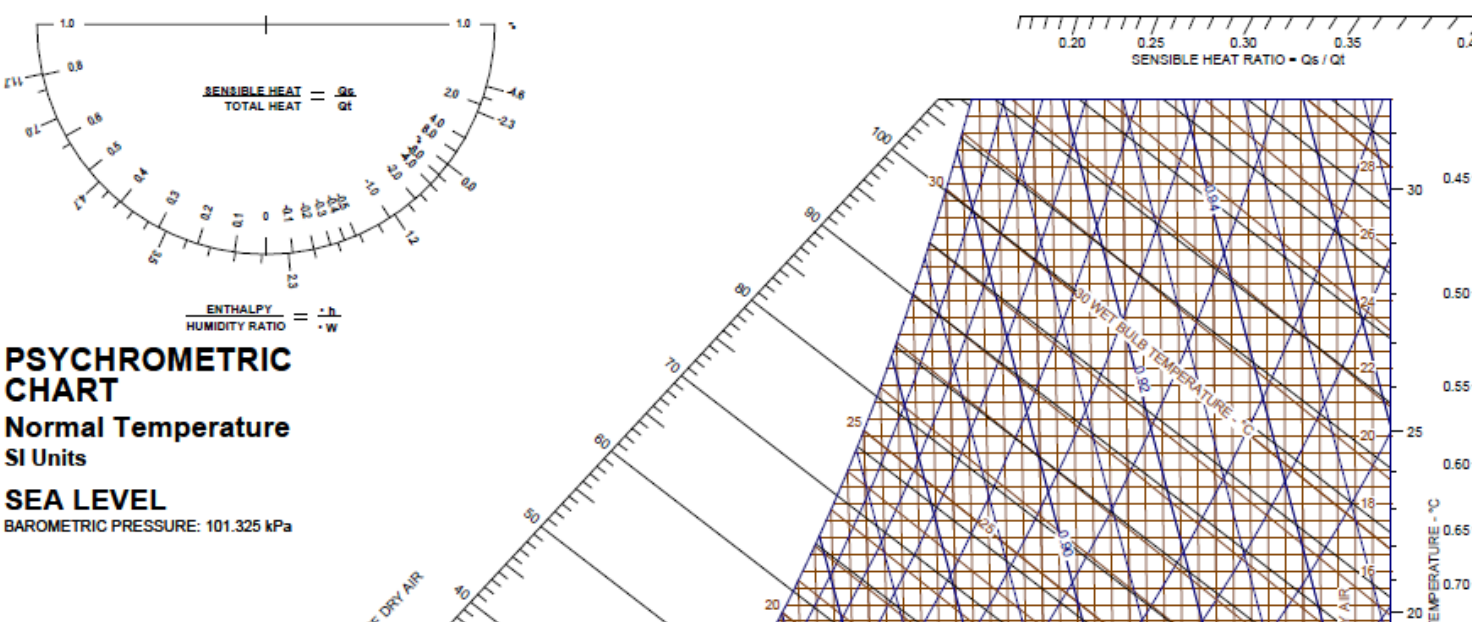
13

Table S1: Modelled internal gains, cooling system set points and daily period of operation used in the calculations.

\begin{tabular}{|l|r|l|}
\hline Attribute & Value & Units \\
\hline Indoor Setpoint Temperature & 23 & ${ }^{\circ} \mathrm{C}$ \\
\hline Relative Humidity (RH) Set-point & 50,60 & $\%$ \\
\hline Period Building Occupied & $7 a m$ to $6 \mathrm{pm}$ & - \\
\hline Occupant Density & 12 & $\mathrm{~m}^{2} /$ person \\
\hline Occupant Heat Gain (sensible) & 60 & $\mathrm{~W} /$ person \\
\hline Occupant Heat Gain (latent) & 40 & $\mathrm{~W} /$ person \\
\hline Equipment Heat Gain (sensible) & 140 & $\mathrm{~W} /$ person \\
\hline Lighting Heat Gain (sensible) & 10 & $\mathrm{~W} / \mathrm{m}^{2}$ \\
\hline
\end{tabular}

Table S2. Wind pressure coefficients of infiltration effects on building cooling requirements.

\begin{tabular}{|l|c|c|c|c|}
\hline \multirow{2}{*}{ Façade Orientation (Height) } & \multicolumn{4}{|c|}{ Wind direction (Degree) ${ }^{* *}$} \\
\cline { 2 - 5 } & $\mathbf{0}$ & $\mathbf{9 0}$ & $\mathbf{1 8 0}$ & $\mathbf{2 7 0}$ \\
\hline South (9m) & -0.017 & -0.039 & 0.02 & -0.039 \\
\hline South (27m) & -0.022 & -0.051 & 0.061 & -0.051 \\
\hline East (9m) & -0.057 & 0.001 & -0.057 & -0.024 \\
\hline East (27m) & -0.028 & -0.116 & -0.028 & -0.012 \\
\hline North (9m) & 0.02 & -0.039 & -0.017 & -0.039 \\
\hline North (27m) & 0.061 & -0.051 & -0.022 & -0.051 \\
\hline West (9m) & -0.057 & -0.024 & -0.057 & 0.001 \\
\hline West (27m) & -0.028 & -0.012 & -0.028 & -0.166 \\
\hline Roof (36m) & 0.008 & 0.008 & 0.008 & 0.008 \\
\hline * Height refers to the height of the location that the C value is calculated for. \\
** Direction of wind is determined from the North, e.g. 90 degrees represents Easterly winds. \\
Derived from: Cpcalc+ for buildings more than 3-storeys in height (Grosso, 1992) \\
\hline
\end{tabular}

